\title{
Identifikasi Candida albicans pada Wanita Dewasa di Kota Kendari secara Makroskopis dan Mikroskopis
}

\author{
${ }^{1}$ Hartati, ${ }^{2}$ Maliftha Dwi Aini, ${ }^{3}$ Yuliyanti Yasin \\ ${ }^{1}$ Fakultas Kedokteran UHO \\ ${ }^{2}$ Program Pendidikan Dokter UHO \\ ${ }^{3}$ Bagian Patologi Klinik RSUP Bahteramas \\ Email: tati_sakti@yahoo.com
}

\begin{abstract}
Background: Candida albicans is a major cause of invasive fungal infections and the common health problems that occur in the community. It was reported that 85-90\% of C. albicans is a major cause of candidiasis vulvovaginalis $(\mathrm{CVV})$ infections worldwide. Reports from the University of Manchester in England and Wayne State University in the United States of America specified that the prevalence of CVV cases in Indonesia is ranked fourth in the world with 4 million cases. Research Purposes: This research aims to determine the macroscopic and microscopic depiction of C. albicans from vaginal swab in Kendari City. Research Methods: The present research is a descriptive study conducted in adult women who visit the Clinical Laboratory Maxima Kendari to do pap smear of both with and without complaints. The total sampling technique was used for collecting 36 samples. The variables being studied consist of independent variables by macroscopically and microscopically and C. albicans is the dependent variable. Research Result The results showed that as of 36 samples of the secret vaginal, 4 samples (11.1\%) were identified positive Candida sp. on direct examination with 10\% KOH, 15 samples (41.7\%) were positive Candida sp. resulting from gram stain test and culture of sabouraud dextrose agar, and there were 12 samples (80\%) detected as positive C. albicans on biochemistry test. Conclusion: Research concluded that $C$. albicans can be identified by both macroscopic and microscopic analysis. As of 36 secret vaginal samples, 6 samples with complaint and 9 samples without complaint positive contain C. albicans, yet 14 samples with complaint and 7 samples without complaint do not detected $C$. albicans.
\end{abstract}

Keywords : Candida albicans, swab vagina, macroscopic, microscopic

\section{PENDUHULUAN}

Candida albicans merupakan penyebab utama infeksi jamur invasif dan merupakan masalah kesehatan umum yang terjadi di masyarakat. Sekitar 50-75\% wanita pernah terinfeksi kandidiasis vulvovaginalis (KVV) semasa hidupnya. Sardi, et al (2013) melaporkan bahwa 8590\% C. albicans merupakan penyebab utama infeksi KVV di dunia. C. albicans dapat menimbulkan masalah kesehatan yang serius oleh karena tingginya angka mortalitas dan morbiditas serta melibatkan biaya ekonomi yang relatif tinggi disebabkan oleh lamanya waktu perawatan dan rawat inap (Lai et al., 2012).

Banyaknya kasus asimtomatis yang ditemukan pada genital wanita yang sehat berkisar 20-50\% (Chijioke et al., 2016).
Sekitar 75\% dari semua wanita sedikitnya pernah mengalami satu episode KVV yang tidak menimbulkan keluhan (asimtomatis) dan $50 \%$ dari mereka mengalami kekambuhan (Sobel et al., 2015). Selain itu, diperkirakan $10-20 \%$ wanita yang tidak mendapatkan pengobatan dan tidak terdiagnosis KVV secara dini akan mengalami komplikasi yang serius (CDC, 2015).

Pemahaman yang belum benar mengenai juga diperburuk dengan tidak terdiagnosisnya dan tidak mendapat pengobatan yang tepat, sehingga menjadi masalah utama kesehatan dan dampak bagi pasien, pasangan seksual maupun dokter. Apabila hal ini terjadi tanpa pemberian intervensi yang tepat dapat mengakibatkan komplikasi yang serius. Komplikasi yang 
tejadi dapat berupa mudahnya transmisi HIV/AIDS, kandidiasis reccurent (berulang), infeksi kronis yang dapat besar dan anus serta infeksi sistemik lainnya berupa abses hati dan otak. Oleh sebab itu, untuk menghindari terjadinya hal tesebut maka perlu dilakukan pemeriksaan lebih lanjut untuk mendeteksi penyebab infeksinya sehingga dapat diberikan pilihan terapi yang tepat (Vorvick, 2011).

Standar Operasional Prosedur (SOP) dalam mendiagnosis infeksi Candida sp. adalah dengan anamnesis, pemeriksaan fisik dan pemeriksaan dilakukan secara makroskopis dan mikroskopis. Kelebihan metode pemeriksaan mikroskopis adalah dapat melihat bentuk atau morfologi dari organisme yang lebih kecil menggunakan mikroskop dan kelebihan secara makroskopis adalah dapat mengamati bentuk organoleptik menggunakan panca indra dengan mendeskripsikan bentuk, warna, bau kemudian dikelompokkan berdasarkan jenis atau spesiesnya (Kemala et al., 2013).

Diagnosis infeksi Candida $s p$. berdasarkan biakan jamur atau kultur merupakan gold standar untuk mendapatkan diagnosis dengan tepat karena memiliki tingkat sensitivitas dan menginvasi ke esophagus, usus halus, usus penunjang. Pemeriksaan penunjang dapat

spesifisitas yang cukup tinggi (Kemala et al., 2013).

\section{METODE PENELITIAN}

Penelitian ini merupakan penelitian deskriptif untuk melihat $C$. albicans dari swab vagina pada wanita dewasa. Penelitian ini pada bulan Februari sampai Maret 2017. Pengambilan sampel dilakukan dengan metode total sampling, dilakukan di Laboratorium Klinik Maxima Kendari. Pemeriksaan Laboratorium (KOH, SDA dan pewarnaan Gram dilakukan di Laboratorium Riset Mikrobiologi Fakultas Kedokteran Universitas Haluoleo. Populasi dalam penelitian ini adalah wanita dewasa dengan atau tanpa keluhan yang berkunjung ke Laboratorium Klinik Maxima Kendari periode waktu bulan Februari sampai Maret 2017. Besar sampel dalam penelitian ini berjumlah 36 yang ditentukan berdasarkan teknik total sampling.

\section{HASIL}

Hasil pemeriksaan dengan
pewarnaan langsung (KOH $10 \%)$,
pewarnaan gram, kultur sabouraud
dextrose agar dari 36 sampel swab vagina
ditunjukkan pada Tabel 1 :

Tabel 1. Hasil pemeriksaan dengan pewarnaan langsung ( $\mathrm{KOH} 10 \%)$, pewarnaan gram, kultur sabouraud dextrose agar (SDA).

Hasil pengujian

\begin{tabular}{lccc}
\hline & KOH $10 \%$ & Gram & Kultur SDA \\
\hline Positif & $4(11,1 \%)$ & $15(41,7 \%)$ & $15(41,7 \%)$ \\
Negatif & $32(88,9 \%)$ & $21(58,3 \%)$ & $21(58,3 \%)$ \\
Jumlah & $36(100 \%)$ & $36(100 \%)$ & $36(100 \%)$ \\
\hline
\end{tabular}


Tabel 1 menunjukkan bahwa dari 36 sampel swab vagina yang dilakukan pemeriksaan langsung $(\mathrm{KOH} \quad 10 \%)$ terdapat 4 sampel $(11,1 \%)$ positif ditemukan jamur (gambar 1) dan 32 sampel $(88,9 \%)$ negatif.

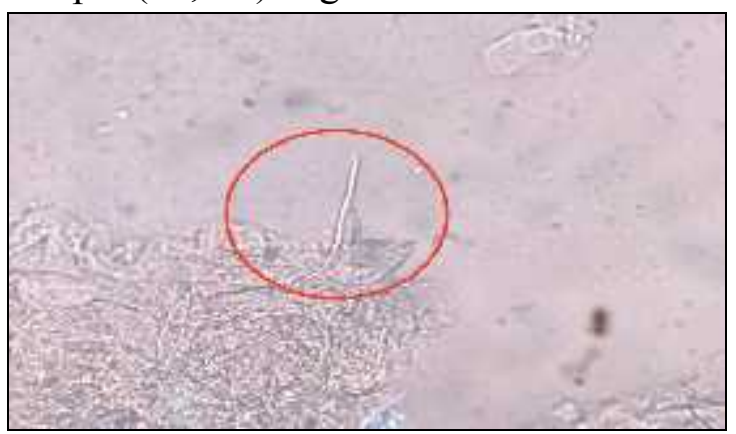

Gambar 1a. Hasil pemeriksaan langsung dengan $\mathrm{KOH} 10 \%$ pada sampel A6 (tampak adanya hifa)

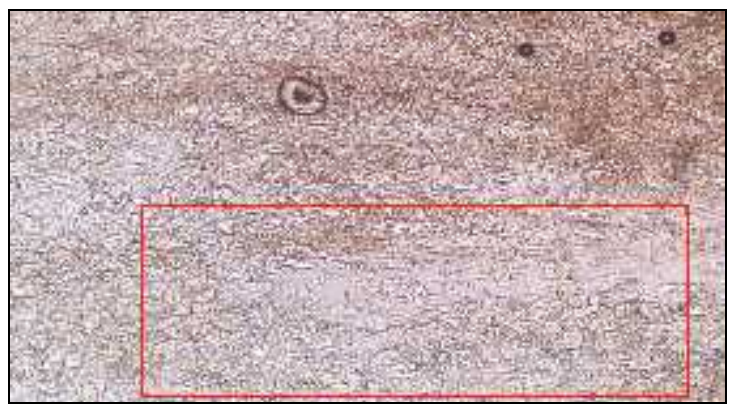

Gambar 1b. Hasil pemeriksaan langsung dengan $\mathrm{KOH} 10 \%$ pada sampel $\mathrm{C} 23$ (tampak adanya spora)

Pada pewarnaan gram terdapat 15 sampel $(41,7 \%)$ positif ditemukan jamur (gambar 2) dan 21 sampel (58,3\%) negatif.

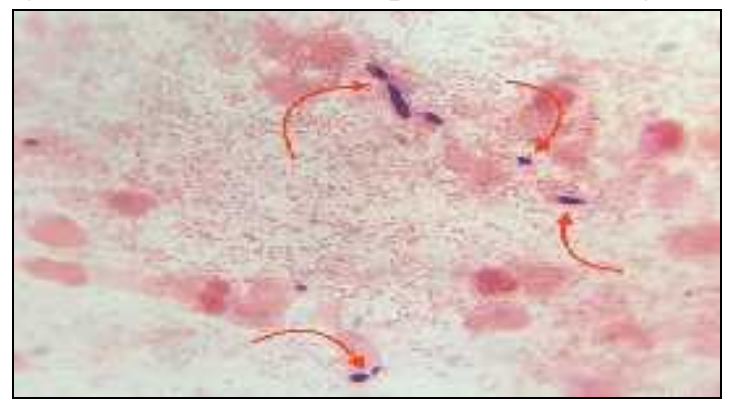

Gambar 2. Hasil pemeriksaan dengan pewarnaan gram pada sampel B11 (tampak adanya budding yeast berwarna ungu)
Pada pemeriksaan dengan kultur sabouraud dextrose agar terdapat 15 sampel $(41,7 \%)$ yang positif ditemukan koloni Candida sp. (gambar 3) dan 21 sampel $(58,3 \%)$ negatif.

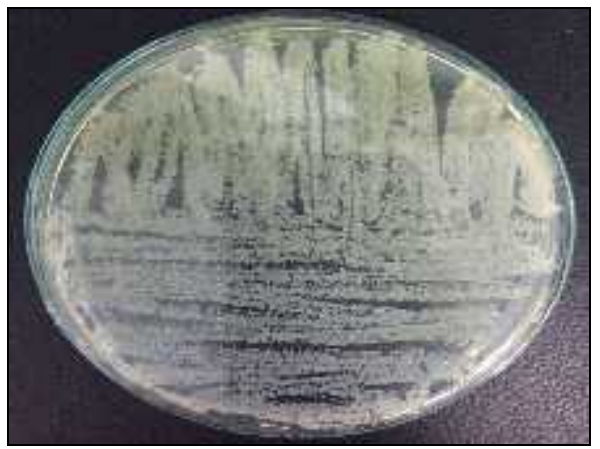

Gambar 3. Hasil pemeriksaan kultur SDA yang positif pada sampel B10 (tampak koloni $C$. albicans berwarna putih, permukaan licin, menonjol disertai bau khas (yeast odor)

Tabel 2. Hasil pemeriksaan dengan uji biokimia

\begin{tabular}{cc}
\hline \multicolumn{2}{c}{ Hasil pengujian } \\
\hline & Uji biokimia \\
\hline Positif & $12(80 \%)$ \\
Negatif & $3(20 \%)$ \\
Jumlah & $15(100 \%)$ \\
\hline
\end{tabular}

Pada uji biokimia yang dilakukan terhadap kultur SDA yang positif, diperoleh 12 sampel (80\%) positif terdeteksi C. albicans (gambar 4) dan 3 sampel $(20 \%)$ negatif.

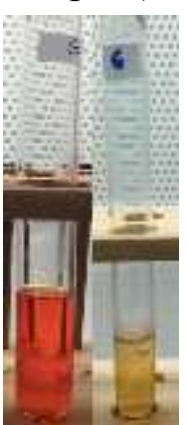

(a)

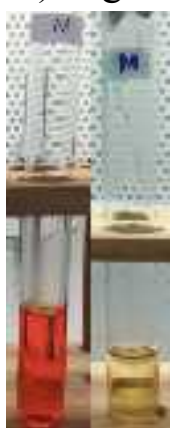

(b)

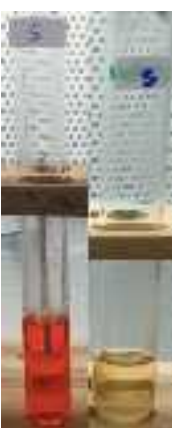

(c)

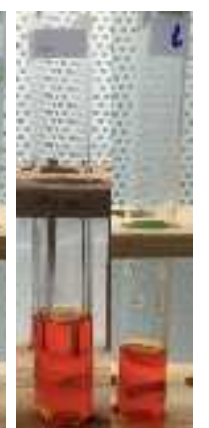

(d)
Gambar 4. Uji biokimia (tes gula-gula) (a) glukosa (b) maltosa (c) sukrosa (d) laktosa. 
Tabel 3. Hasil pemeriksaan langsung $\mathrm{KOH}$ $10 \%$ dibandingkan dengan kultur sabouraud dextrose agar (SDA)

\begin{tabular}{ccccc}
\hline $\begin{array}{c}\text { Metode } \\
\text { identifikasi }\end{array}$ & \multicolumn{5}{l}{ Hasil pemeriksaan } \\
\hline KOH 10\% & + & - & - & + \\
Kultur SDA & + & + & - & - \\
\hline \multicolumn{5}{c}{36} \\
\hline Jumlah & 4 & 11 & 21 & 0 \\
\hline
\end{tabular}

Berdasarkan tabel diatas sampel yang positif pada pemeriksaan langsung dengan $\mathrm{KOH} 10 \%$ dan negatif pada kultur SDA berjumlah 4 sampel. Sampel yang positif pada pemeriksaan langsung dengan $\mathrm{KOH} 10 \%$ dan positif pada kultur SDA berjumlah 32 sampel. Sampel yang negatif pada pemeriksaan langsung dengan $\mathrm{KOH}$ $10 \%$ dan negatif pada kultur SDA berjumlah 21 sampel.

\section{PEMBAHASAN}

Pemeriksaan yang dilakukan pada penelitian ini diantaranya meliputi pemeriksaan langsung dengan $\mathrm{KOH} 10 \%$, pewarnaan Gram, kultur SDA dan uji biokimia. Hasil pemeriksan menunjukkan bahwa pemeriksaan langsung dengan $\mathrm{KOH} \quad 10 \%$ yang diamati dibawah mikroskop pada pembesaran 40x ditemukan hifa dan spora. Hasil pemeriksaan pada pewarnaan gram yang diamati dibawah mikroskop pada pembesaran $100 \mathrm{x}$ ditemukan sel ragi (budding yeast cell) yang berbentuk oval dengan didominasi warna ungu. Hasil pemeriksaan dengan kultur SDA ditemukan Candida sp. dengan koloni berwarna putih, permukaan licin, menonjol disertai bau khas (yeast odour. Hasil pemeriksaan dengan uji biokimia sebagai tes penunjang diperoleh sampel positif terdeteksi $C$. albicans. Fermentasi jamur ini menunjukkan hasil terbentuknya asam dan gas pada glukosa, terbentuknya asam pada maltosa dan sukrosa dan tidak terbentuk asam pada laktosa.

Pemeriksaan langsung dengan $\mathrm{KOH} \quad 10 \%$ merupakan pemeriksaan sederhana dan membutuhkan waktu yang relatif cepat untuk mendeteksi adanya jamur. Pemeriksaan langsung dengan larutan $\mathrm{KOH}$ dapat berhasil bila jumlah jamur cukup banyak. Pemeriksaan dengan $\mathrm{KOH} \mathrm{10 \%} \mathrm{memiliki} \mathrm{beberapa} \mathrm{kelemahan}$ yaitu sensitivitas yang bervariasi $65-85 \%$ atau lebih rendah, sering tidak konsisten, membutuhkan tenaga laboratorik terampil dan berpengalaman dalam hal prosedur pembacaan preparat. Pemeriksaan ini membutuhkan tiga kali pemeriksaan mikroskopik pada pasien dengan hasil laboratorik awalnya negatif untuk menginterpretasikan keberadaan elemen jamur (Kemala et al, 2013).

Pemeriksaan dengan pewarnaan gram adalah salah satu pemeriksaan yang dapat dilakukan untuk menentukan adanya jamur. Berdasarkan hasil penelitian, pemeriksaan ini dapat digunakan sebagai tes alternatif dalam mengidentifikasi adanya jamur. Pemeriksaan ini dapat melihat jamur berdasarkan morfologinya, tetapi tidak dapat mengidentifikasi spesiesnya dan sedikit membutuhkan waktu dibandingkan dengan pemeriksaan langsung menggunakan $\mathrm{KOH} \quad 10 \%$ (Mutiawati, 2016).

Kultur sabouraud dextrose agar merupakan pemeriksaan baku emas untuk mendeteksi adanya jamur. Dari 15 sampel yang ditumbuhi koloni dilakukan uji mikroskopis dengan pewarnaan gram. Hasil uji menunjukkan adanya hifa serta sel ragi (budding yeast cell) berbentuk oval dan berwarna ungu. Pembiakan dilakukan sebagai alat konfirmasi jika 
pada pasien terdapat gejala klinis yang khas namun pada pemeriksaan laboratorium negatif. Sensitivitas pada biakan jamur mencapai 90-100\% (Adinda, 2013).

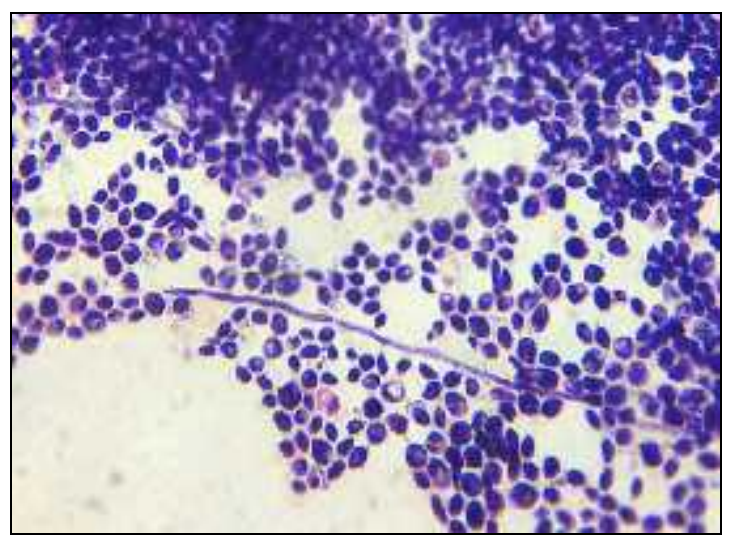

Gambar 5. Pewarnaan Gram pada sampel B10 tampak adanya hifa serta sel ragi (budding yeast cell) berbentuk oval dan berwarna ungu)

C. albicans dapat dibedakan dari spesies lain berdasarkan kemampuannya melakukan proses fermentasi. Koloni yang tumbuh pada SDA dilakukan pemeriksaan penunjang yaitu uji biokimia (uji karbohidrat) antara lain uji (glukosa, sukrosa, laktosa dan maltosa). Adanya pembentukan asam atau fermentasi ini ditandai dengan perubahan warna medium karbohidrat dari merah menjadi kuning sedangkan pembentukan gas dapat dilihat dengan adanya gelembung gas pada tabung durham (Dewi, 2014).

Penelitian ini menunjukkan bahwa tidak semua jamur dapat di deteksi pada pemeriksaan langsung dengan $\mathrm{KOH} 10 \%$. Adapun faktor-faktor yang dapat mempengaruhi adalah pengambilan sampel serta cara pembuatan apusan swab vagina tidak benar dan pemeriksaan langsung tidak segera dilakukan setelah apusan swab vagina diperoleh sebab jamur khususnya $C$. albicans dapat berkembang cepat pada suhu kamar sehingga dapat memberikan gambaran yang tidak sesuai dengan keadaan klinis. Selain itu, kurang terampilnya tenaga laboratorik dalam hal prosedur pembacaan preparat dapat menjadi faktor kegagalan dalam mendeteksi keberadaan jamur.

\section{KESIMPULAN}

Candida albicans dapat ditemukan pada pemeriksaan secara makroskopis yaitu dari 36 sampel swab vagina diperoleh $15(41,7 \%)$ sampel positif ditumbuhi koloni Candida sp. pada pemeriksaan kultur SDA dan dari 15 sampel tersebut ditemukan 12 sampel positif terdeteksi C. albicans pada uji biokimia.

C. albicans dapat ditemukan pada pemeriksaan secara mikroskopis yaitu dari 36 sampel swab vagina diperoleh 4 $(11,1 \%)$ positif pada pemeriksaan langsung $\mathrm{KOH} \quad 10 \%$ dan $15 \quad(41,7 \%)$ sampel positif pada pewarnaan gram.

Hasil penelitian dari 36 sampel sekret vagina wanita dewasa yang diteliti, 6 sampel dengan keluhan dan 9 sampel tanpa keluhan positif ditemukan C.albicans sedangkan pada 14 sampel dengan keluhan dan 7 sampel tanpa keluhan tidak ditemukan C. albicans.

\section{SARAN}

Pemeriksaan langsung dengan $\mathrm{KOH} \quad 10 \%$ disarankan untuk tidak digunakan sebagai satu-satunya cara untuk mendeteksi Candida albicans jika tidak disertai dengan pemeriksaan inspeksi pada vagina.

Menghimbau kepada para wanita dewasa khususnya agar lebih peduli dan memperhatikan kesehatan saluran reproduksi. Selain itu, wanita yang telah 
terdiagnosis kandidiasis perlu diberikan pengobatan antijamur.

Populasi target yang diperiksa diperluas hingga mencakup wanita dengan risiko tinggi.

\section{DAFTAR PUSTAKA}

Adinda, R., Ridhawati, MS. 2013. Prevalensi Kandidosis Vagina di Departemen Parasitologi tahun 2010-2011. FKUI Jakarta.

Anindita, W. dan Martini, S. 2006. Faktor Risiko Kejadian Kandidiasis Vaginalis pada Akseptor KB .The Indonesian Journal of Public Health. Vol. 3. No. 1. Juli. 2006. 24-28.

Center for Disease Control and Prevention. Sexually Transmitted Disease Treatment Guidelines. 2015. http://www.cdc.gov/std/tg2015/candi diasis.htm (diakses tanggal 4 Desember 2016).

Chijioke A. Nsofor, Cynthia E. Obijuru, Chika V. Ohalete. 2016. High Prevalence of Candida albicans Observed in Asymptomatic Young Women in Owerri Nigeria. Biomedicine and Biotechnology vol.4, No.1-4

Dewi P.V., Nurwaniansah Rani. 2014. Pemeriksaan Kontaminasi Candida albicans Pada Air Kolam Renang Di Kota Tasikmalaya. Jurnal Kesehatan Bakti Tunas Husada Vol. 11 No.1 Februari.

J. C. O. Sardi, L. Scorzoni, T. Bernardi, A. M. Fusco-Almeida and M. J. S. Mendes Giannini. 2013. Candida species: current epidemiology, pathogenicity, biofilm formation, natural antifungal products and new therapeutic options. 62: 10-24.

Kemala, S., Athuf, T., Soenarto. R.M Suryadi Tjekyan. Nilai Diagnostik Rapid Yeast Test Untuk Diagnosis Kandidiasis Vulvovaginalis Pada Wanita Pekerja Seks Komersial di Klinik Graha Sriwijaya Palembang. MKS, Th. 45, No. 1, Januari 2013.

Lai, C.C., Wang, C.Y., Liu, W.L., Huang, Y.T. \& Hsueh, P.R. 2012. Time to positivity of blood cultures of different Candida species causing fungaemia. J Med Microbiol, 61: 701-704.

Mutiawati, V.M. 2016. Pemeriksaan mikrobiologi pada Candida albicans. Jurnal Kedokteran Syiah Kuala, 1: 53-63.

Sobel JD. 2015. Reccurent Vulvovaginalis Candidiasis. American Journal of Obstetrics and Gynecology.

Vorvick L.J. 2011. Vaginal Yeast Infection.

http://www.nlm.nih.gov/medlineplus /ency/article/001511.html (diakses tanggal 25 November 2017). 